\title{
Increased Catecholamine Levels and Inflammatory Mediators Alter Barrier Properties of Brain Microvascular Endothelial Cells in vitro
}

\author{
Cora Ittner ${ }^{1}$, Malgorzata Burek ${ }^{1}$, Stefan Störk ${ }^{2}$, Michiaki Nagai $^{3}$ and Carola Y. Förster ${ }^{1 *}$ \\ ${ }^{1}$ Department of Anaesthesia and Critical Care, University of Würzburg, Würzburg, Germany, ${ }^{2}$ Comprehensive Heart Failure \\ Center, University of Würzburg, Würzburg, Germany, ${ }^{3}$ Department of Internal Medicine, General Medicine and Cardiology, \\ Hiroshima City Asa Hospital, Hiroshima, Japan
}

OPEN ACCESS

Edited by:

Mauricio Boric P.,

Pontifical Catholic University of

Chile, Chile

Reviewed by:

Christoph Eugen Hagemeyer,

Monash University, Australia

Adriana Georgescu,

Institute of Cellular Biology and

Pathology (ICBP), Romania

*Correspondence:

Carola Y. Förster

Foerster_C@ukw.de

Specialty section:

This article was submitted to

Atherosclerosis and Vascular

Medicine,

a section of the journa

Frontiers in Cardiovascular Medicine

Received: 03 February 2020

Accepted: 14 April 2020

Published: 05 May 2020

Citation:

Ittner C, Burek M, Störk S, Nagai M and Förster CY (2020) Increased

Catecholamine Levels and Inflammatory Mediators Alter Barrier

Properties of Brain Microvascular Endothelial Cells in vitro.

Front. Cardiovasc. Med. 7:73 doi: 10.3389/fcvm.2020.00073
Recent studies have suggested a pathogenetic link between ischemic stroke and Takotsubo cardiomyopathy (TCM) with poor outcome, when occurring simultaneously. Increased catecholamine (CAT) levels as well as elevated inflammatory mediators (INF) are found in the blood of patients with ischemic stroke concomitant with Takotsubo syndrome (TTS). On molecular level, the impact of these stressors combined with hypoxemia could compromise the integrity of the blood brain barrier (BBB) resulting in poor outcomes. As a first step in the direction of investigating possible molecular mechanisms, an in vitro model of the described pathological constellation was designed. An immortalized murine microvascular endothelial cell line from the cerebral cortex (CEND) was used as an established in vitro model of the BBB. cEND cells were treated with supraphysiological concentrations of CAT (dopamine, norepinephrine, epinephrine) and INF (TNF- $\alpha$ and Interleukin-6). Simultaneously, cells were exposed to oxygen glucose deprivation (OGD) as an established in vitro model of ischemic stroke with/without subsequent reoxygenation. We investigated the impact on cell morphology and cell number by immunofluorescence staining. Furthermore, alterations of selected tight and adherens junction proteins forming paracellular barrier as well as integrins mediating cell-matrix adhesion were determined by RT-PCR and/or Western Blot technique. Especially by choosing this wide range of targets, we give a detailed overview of molecular changes leading to compromised barrier properties. Our data show that the proteins forming the BBB and the cell count are clearly influenced by CAT and INF applied under OGD conditions. Most of the investigated proteins are downregulated, so a negative impact on barrier integrity can be assumed. The structures affected by treatment with CAT and INF are potential targets for future therapies in ischemic stroke and TTS.

Keywords: blood-brain barrier, microvascular endothelium, cEND cell line, takotsubo syndrome, catecholamines, inflammation, in vitro 


\section{INTRODUCTION}

Recent clinical publications and literature reviews point out that takotsubo syndrome (TTS) occurring in combination with ischemic stroke is a notable clinical constellation (1). The link between these two pathologies is not well-understood yet, especially not on molecular level.

Takotsubo cardiomyopathy (TCM) is a cardiac pathology at first glance mimicking acute coronary syndrome (ACS). The most important clinical feature is the absence of coronary occlusion which differentiates TCM from ACS (2). Characteristic wall motion abnormalities predominantly affecting the left ventricle are observed. This phenomenon is described as apical ballooning. Patients are mostly postmenopausal women, who present dyspnea, chest pain as well as new ECG alterations and/or elevated cardiac enzymes (2). Precursory cerebrovascular disease no longer interdicts to diagnose TCM. In one to two thirds of patients suffering from TCM, a previous psychically or physically stressful trigger can be identified $(3,4)$.

Interestingly, there is no strict sequence, whether ischemic stroke or TCM develop first. Ischemic stroke is described as a neurological precipitant of TTS. In contrast, thrombus formation caused by left ventricular dysfunction within TCM can also lead to ischemic stroke. Hereby, ischemic strokes in patients with TTS are usually severe and classified by an initially higher NIHSS score in comparison with patients without TTS. Poor outcomes are frequent in the patients of ischemic stroke with TTS $(1,5)$.

Patients presenting the described pathological pattern, show characteristically altered laboratory findings: Supraphysiological CAT blood levels can be determined (6). This reflects the plausible theory of TTS pathogenesis consisting in raised CAT, which are assumed to mediate myocardial wall motion abnormalities (3). Furthermore, elevated inflammatory markers are found (1). This correlates with the known fact of raised INF in ischemic areas after stroke. Resident cerebral immune cells as well as migrated immune cells synthesize, inter alia, pro-inflammatory cytokines like TNF- $\alpha$ and IL-6 (7). Especially cardioembolic strokes are associated with increased CRP, TNF$\alpha$, and IL- 6 levels compared to other subtypes of ischemic insults (8). Although, the role of the two mentioned cytokines is still diversely discussed, clinical and experimental data suggest an aggravation of ischemic brain damage by inflammatory spillover. Furthermore, dysfunction of the cerebral microvascular endothelium in the frame of ischemic stroke is promoted by systemic inflammation (7).

The depicted clinical situation presents a pathological process within the brain-heart axis. In general, the brain-heart axis is a dual system, which works up and down stream: cardiac dysfunction may trigger neurovascular deterioration and vice versa (9). Ischemic stroke and TCM seem to interact due to the influence of the insular cortex on the modulation of the autonomic nervous system. In vivo animal models as well as human studies have shown ischemic lesions affecting the insular cortex cause autonomic dysregulation (10), especially when concerning the left hemisphere, the impairment of the insular cortex produces a sympathetic overdrive reflected by elevated CAT levels (11). Clinical findings correspondingly suggest a predominance of ischemic strokes affecting the insular cortex and/or adjacent brain regions preceding TTS (12).

As part of the brain-heart axis, the $\mathrm{BBB}$ reacts to hypoxic events caused by cardiac impairment and vice versa (9). Therefore, when investigating pathologies of the brain-heart axis the $\mathrm{BBB}$ has to be included in speculation on possible pathogenetic mechanisms.

Sustained integrity of the BBB is mandatory for maintaining the homeostasis of the central nervous system (CNS). Thus, the CNS gets its unique position by not being exposed unselectively to systemic alterations such as inflammation (13). Restricted permeability is provided by microvascular endothelial cells forming dense cell-cell contacts: a dynamic interface is ensured by tight junctions (TJ) and adherens junctions (AJ) building a restrictive barrier $(14,15)$. If circulating noxious agents affect vascular endothelium itself, TJ as well as AJ could not be maintained properly leading to a breakdown of the BBB (16). Cerebral vascular endothelium forming the $\mathrm{BBB}$, on its blood facing side, is constantly exposed to systemically circulating INF, and elevated CAT blood levels. The proinflammatory cytokines TNF- $\alpha$ and IL- 6 , as elevated in acute TTS (1) are proven to be harmful factors for the integrity of the $\mathrm{BBB}$ by compromising TJ protein as well as AJ protein expression in vitro $(17,18)$. Systemical administration of epinephrine lead to a disruption of the BBB in vivo (19). Furthermore, focal ischemia results in a breakdown of the $\mathrm{BBB}$, which produces increased permeability. Aggravation of brain damage by secondary effects such as brain edema is provoked (13). TJ proteins claudin-5, occludin as well as AJ protein VEcadherin were shown to be targets of hypoxic conditons in vitro (20).

Based on these assumptions, we suggest that the severity of ischemic stroke in patients with TTS is caused by aggravated dysfunction of the BBB. An intensified impairment of the vascular endothelial cells generated by elevated CAT levels and INF combined with hypoxia is hypothesized. As a first step of investigating this pathologic constellation, an in vitro experiment was designed. Supraphysiological CAT levels combined with INF were applied under OGD (20). An immortalized murine cerebral endothelial cell line (cEND) was chosen as a well-established in vitro model of the $\mathrm{BBB}(21)$. The present study provides a comprehensive overview of molecular changes of cerebral microvascular endothelium, exposed to an in vitro simulation of characteristic laboratory findings in patients suffering from TTS and ischemic stroke simultaneously.

\section{MATERIALS AND METHODS}

\section{Chemicals}

TNF- $\alpha$, Dopamine, Epinephrine as well as Norepinephrine were purchased from Sigma-Aldrich. Interleukin-6 was purchased from Thermo Fisher. Epinephrine and Norepinephrine were dissolved in $0.5 \mathrm{M}$ hydrochloric acid, Interleukin-6 in $100 \mathrm{nM}$ acetic acid. TNF- $\alpha$ and Dopamine are readily soluble in water, so cell culture medium was used for dissolving. Final dilution of every agent was made shortly before the experiment in cell culture medium. 


\section{Cell Culture}

As an in vitro model of the Blood Brain Barrier (BBB) we used the murine microvascular cerebral endothelial cell line cEND. Cells were isolated, immortalized, and cultivated as described previously (21-23).

\section{Cell Treatment}

Cells were grown to confluence within 5 days in Dulbeccos's modified eagles medium (DMEM) growth medium on 6-wellplates coated with gelatin. Growth medium consisted of DMEM (Sigma-Aldrich, D5796) containing 10\% heat-inactivated fetal calf serum (FCS), $50 \mathrm{U} / \mathrm{ml}$ penicillin-streptomycin, 2\% Lglutamine, 2\% MEM vitamins, $2 \%$ non-essential amino acid solution (NEAA), and $2 \%$ sodium pyruvate. Subsequently, cells were differentiated for $48 \mathrm{~h}$ with DMEM differentiation medium containing $1 \%$ FCS as well as $50 \mathrm{U} / \mathrm{ml}$ penicillin-streptomycin. Stress factors were applied under different incubation conditions. Stress factors were defined as a combination of CAT [150 $\mu \mathrm{M}$ dopamine (24), $1 \mu \mathrm{M}$ epinephrine (25), $1 \mu \mathrm{M}$ norepinephrine (25)], and INF [100 nM TNF- $\alpha$ (18) and $5 \mathrm{pg} / \mathrm{ml}$ Interleukin6 (26)]. For application on cells, stress factors were diluted to final concentration in DMEM differentiation medium or DMEM medium without glucose. Solvent of each agent was added in same concentration to control.

\section{Oxygen Glucose Deprivation (OGD) and Reoxygenation}

After differentiation cells were washed twice with PBS. Subsequently, $1.5 \mathrm{ml}$ DMEM without glucose per well were added, followed by incubation under OGD condition for $4 \mathrm{~h}$. OGD condition was defined as $1 \% \mathrm{O}_{2}, 5 \% \mathrm{CO}_{2}, 37^{\circ} \mathrm{C}$ and saturated humidity atmosphere as previously described (20). Control was incubated simultaneously under normoxia condition in $1.5 \mathrm{ml}$ DMEM medium containing glucose per well. After OGD, samples were analyzed directly or reoxygenated for $20 \mathrm{~h}$. Reoxygenation was conducted by washing cells twice with PBS, adding $3 \mathrm{ml}$ DMEM medium containing glucose per well and incubation under normoxia condition $\left(5 \% \mathrm{CO}_{2}, 37^{\circ} \mathrm{C}\right.$, saturated humidity atmosphere) $(20,27)$.

\section{Immunofluorescence Staining}

Cells were cultivated on collagen IV-coated coverslips (diameter of $12 \mathrm{~mm}$ ). Cultivation was conducted as described above. After finished treatment, cells were washed twice with PBS. Fixation for $10 \mathrm{~min}$, with ice-cold methanol, followed by washing (twice; PBS), and $15 \mathrm{~min}$, of PBS containing 1\% BSA. Before incubation with primary antibodies overnight at $4^{\circ} \mathrm{C}$, samples were blocked for $1 \mathrm{~h}$ at RT with PBS containing 1\% BSA and 5\% normal swine serum. As primary antibodies were chosen: Claudin-5 (1:500; Thermo Fisher (Alexa fluor), \#352588) and ZO-1 (1:500; Thermo Fisher, \#402300) diluted in PBS with 1\% BSA/ 5\% normal swine serum. After washing ( 3 times for $5 \mathrm{~min}$. with $\mathrm{PBS}$ ), secondary antibodies diluted in PBS with 1\% BSA/ 5\% normal swine serum were applied: DAPI (1:3000; Sigma-Aldrich, \#D9542) and Alexa fluor 594 donkey anti rabbit IgG (1:2000; Thermo Fisher, \#A21207). Coverslips were fixed onto slides by using Mountant permaflour (Thermo Fisher, \#TA-030-FM) and dried overnight at RT. Subsequently, analysis was performed with a Keyence fluorescence microscope (BIOREVO BZ-9000). The number of cells with intact DAPI-stained nuclei was estimated by counting the nuclei in a defined area of interest for each treatment.

\section{Western Blot Analysis}

Western Blot analysis were performed as previously described (28). Briefly, cells were washed twice with ice cold PBS before being lysed in RIPA buffer containing protease inhibitors cocktail (Roche) and harvested. After sonication (10 times for $0.5 \mathrm{sec}$ on ice), samples were centrifuged (11,000 $\mathrm{rcf}$ for $1 \mathrm{~min}$ ) and supernatant was saved for quantification of protein content. Protein content was determined by BCA protein Assay Kit (Thermo Fisher). Protein separation was conducted using NuPAGE Kit (Thermo Fisher). Previously, samples were mixed with Laemmli buffer and reducing agent as indicated, followed by denaturation of $10 \mathrm{~min}$. at $70^{\circ} \mathrm{C}$. A NuPage $4-12 \%$ Bis-TrisGel (Thermo Fisher) was used for separation. The blot to a PVDF membrane was accomplished by electrophoretically wet transfer overnight $\left(4^{\circ} \mathrm{C}\right)$ using a Electrophoretic Transfer Cell (BioRad). Subsequently, membrane was washed in PBS-T (3 times for 10 min.), blocked with 5\% non-fat dry milk in PBS ( $1 \mathrm{~h})$ and incubated overnight $\left(4^{\circ} \mathrm{C}\right)$ with the primary antibody diluted in PBS containing 1\% BSA. As primary antibodies we used: mouse anti-claudin-5 (1:500; Thermo Fisher, \#35-2500), guinea pig anti-occludin (1:200; Acris, \#358-504), rabbit anti-ZO-1 [1:500; Thermo Fisher, \#40-2300), rat anti-VE-cadherin [pure; generated with hybridoma technique (29)] and anti-ß-aktin-HRP (1:25.000; Sigma-Aldrich, \#A3854). Before applying secondary antibodies, membrane was washed with PBS-T (PBS with addition of $0.1 \%$ Tween) (3 times for $10 \mathrm{~min}$ ) and blocked with 5\% non-fat dry milk in PBS (20 min). Secondary antibodies were: anti-mouse IgG (1:3000; Roche, \#12015218001), anti-guinea pig IgG (1:5000; Santa Cruz Biotechnology, \#sc2438), anti-rabbit IgG (1:3000; Cell Signaling Technology, \#7074S), and anti-rat IgG (1:5000; Thermo Fisher, Cat\#61-9520). After washing the membrane with PBS-T (3 times for $10 \mathrm{~min}$ ), incubation in ECL solution (2 min) followed. For imaging, Fluorchem FC2 MultiImager II (AlphaInnotech) was used. Density of protein bands was determined by ImageJ software (version 1.52a).

\section{Real-Time PCR}

Real-time PCR analysis were performed as previously described (30). Briefly, cells were washed twice with sterile PBS. Subsequently, samples were harvested and RNA was isolated as well as purified from lysed cells following manufacterer's instructions of Nucleospin RNA (Macherey-Nagel, \#740955). Reverse transcription for generating cDNA was performed by using High Capacity cDNA Reverse Transcription Kit (Applied Biosystems, \#4368814). TaqMan Fast Advanced Master Mix (Applied Biosystems, \#4444557) with $1 \mu \mathrm{g}$ cDNA for RT-PCR. For determining gene expression, the following TagMan Gene Expression Assay primers were chosen: Claudin-5 (Mm00727012_s1), occludin (Mm00500912_m1), ZO-1 (Mm00493699_m1), VE-cadherin (Mm00486938_m1), Itg $\alpha 1$ (Mm01306375_m1), Itg $\alpha \mathrm{V} \quad\left(\mathrm{Mm} 00434486 \_m 1\right) . \quad$ All purchased from Thermo Fisher. Calnexin RNA was used as the 
housekeeping gene (Canx; Mm00500330_m1). Subsequently, reverse transcription and amplification was conducted by using 7300 Real Time PCR System (Applied Biosystems) and under the following conditions: $95^{\circ} \mathrm{C}$ for $10 \mathrm{~min}, 50$ cycles for each target, $60^{\circ} \mathrm{C}$ for $1 \mathrm{~min}$.

\section{Analysis and Statistics}

Data are presented as mean \pm standard error of the mean (SEM). Number of independent experiments is indicated under figures. Statistical significance was evaluated by One-way ANOVA with Tukey's correction for multiple comparison using GraphPad Prism. Statistical significance was assumed for $P<0.05$.

\section{RESULTS}

We wanted to examine, whether supraphysiological CAT concentrations and INF, as found in TTS patients (1), change AJ and TJ structure under normoxic and ischemic conditions. We chose $\mathrm{VE}$-cadherin as a representative of $\mathrm{AJ}$ proteins and claudin$5, \mathrm{ZO}-1$ as well as occludin as representative of TJ proteins. In addition, integrin- $\alpha-1$, and integrin- $\alpha$-v were selected as targets reflecting the possible interaction with extracellular matrix (ECM) components. Integrin- $\alpha-1$, a subunit of the collagen receptor integrin $\alpha 1 \beta 1$, binds collagen type IV (31), whereas integrin $-\alpha-\mathrm{v}$ forms part of the vitronectin receptor $\alpha \mathrm{v} \beta 3$ (32). We used cEND cells, an immortalized murine microvascular endothelial cell line from the cerebral cortex, which is a wellestablished in vitro model of the BBB (21).

\section{Barrier Compromising Effects of Catecholamines and Inflammatory Mediators on cEND Cells Under Normoxic Conditions}

To investigate how CAT or INF affect cEND cells, we treated cEND cells for $24 \mathrm{~h}$ under standard culturing conditions, called normoxia conditions (24h NORMOX). We used a mixture of $150 \mu \mathrm{M}$ dopamine (24), $1 \mu \mathrm{M}$ epinephrine (25), and $1 \mu \mathrm{M}$ norepinephrine (25) for CAT samples. Treatment with INF consisted of $100 \mathrm{nM}$ TNF- $\alpha$ (18) and $5 \mathrm{pg} / \mathrm{ml}$ Interleukin- 6 (26). All stressors were diluted in differentiation medium (1\% FCS) to final concentration. Potential effects on cell morphology were determined by staining of cell-cell junctions using anticlaudin-5 and ZO-1 antibodies (Figure 1). As observed in control samples, the expressed claudin-5 and ZO-1 were located at the cell-cell contacts (Figures 1A,B) (21). After treatment with CAT or INF, the cell morphology was altered and the localization of junctional proteins at cell-cell junction sites was reduced. Treatment with CAT resulted in a disruption of the homogenous cell monolayer, while the cellular morphology was still spindleshaped (Figure 1A). The percentage of cells with intact nuclei was significantly lower in samples treated with CAT compared to the control (Figure 1C). cEND cells lost their elongated spindleshaped morphology (21) due to treatment with INF and showed more cobble-stone-like phenotype (Figure 1B). The number of cells with intact nuclei was also significantly lower than in the untreated control (Figure 1C). As demonstrated in Figure 1C,
CAT alone caused a stronger breakdown of the homogenous cell monolayer compared to INF. A lower number of cells with intact nuclei indicates that CAT and INF treatment induces cell death in cEND cells.

To investigate whether the barrier properties of cEND cells are also affected at the protein and mRNA, cells were treated as described above. Subsequently, RT-PCR and Western Blot were performed (Figure 1, Table 1). Protein level of ZO-1 was reduced by $0.57 \pm 0.04$-fold while claudin-5, occludin and VE-cadherin were not altered by the administration of CAT (Figure 1D). CAT caused a decreased gene expression of claudin-5 to $0.47 \pm 0.02$ fold, $\mathrm{ZO}-1$ to $0.38 \pm 0.05$-fold, and VE-cadherin to $0.55 \pm 0.02$ fold of control. A change in the mRNA level of occludin could not be detected. Integrin- $\alpha-1$ mRNA was decreased by $0.19 \pm$ 0.02 -fold while integrin- $\alpha$-v expression increased up to $1.82 \pm$ 0.24 -fold of control. Protein expression of selected targets was not significantly altered by INF (results not shown). INF led to impaired gene expression of occludin $(0.39 \pm 0.05$-fold $), \mathrm{ZO}-1$ $(0.51 \pm 0.05$-fold $)$, and VE-cadherin $(0.85 \pm 0.02$-fold $)$, but did not alter claudin- 5 mRNA level. Integrin- $\alpha-\mathrm{v}$ gene expression increased up to $3.31 \pm 0.54$-fold after INF treatment, while no differences were detected in integrin- $\alpha-1$ mRNA level (Table 1).

\section{Barrier Compromising Effects of Catecholamine Levels and Inflammatory Mediators on cEND Cells in Hypoxic Condition In vitro}

We combined elevated levels of CAT and INF with hypoxic and hypoglycemic conditions called oxygen glucose deprivation (OGD) with or without subsequent reoxygenation. OGD was previously established in cEND as an in vitro model of ischemic stroke (20). From that point on, CAT and INF were combined and labeled as stress factors. Stress factors were diluted to final concentration in differentiation or glucose-free medium to be used under selected incubation conditions. Four different incubation conditions were defined: $4 \mathrm{~h}$ of normoxia $(4 \mathrm{~h}$ NORMOX), $24 \mathrm{~h}$ of normoxia (24h NORMOX), $4 \mathrm{~h}$ of OGD, and $4 \mathrm{~h}$ of OGD with subsequent reoxygenation under normoxia condition (REOX).

First, we analyzed the cell morphology after these treatments. The cells were grown on coverslips, differentiated, and incubated as described above (Figure 2). Possible effects on cell morphology were determined by staining of TJs with anti-claudin- 5 and -ZO-1 antibodies. Cells grown without stress factors under normoxia conditions (4h NORMOX and $24 \mathrm{~h}$ NORMOX) as well as OGD condition showed no changes in the cell morphology (Figures 2A-C) nor in cell number (Figure 2E). cEND cells showed a homogenous endothelial monolayer and the typical elongated spindle-shaped morphology as described before $(21,22)$ Both stained TJ proteins, claudin-5, and ZO1 , were located at the TJs (Figures $\mathbf{2 A}-\mathbf{C}$ ). The reoxygenation sample without stress factors showed a disrupted cell monolayer with irregular cellular morphology and delocalized TJ-proteins (Figure 2D) but no reduced cell number (Figure 2E). The effects of stress factors applied under normoxia conditions depended on time. After $4 \mathrm{~h}$ of treatment, endothelial cell 

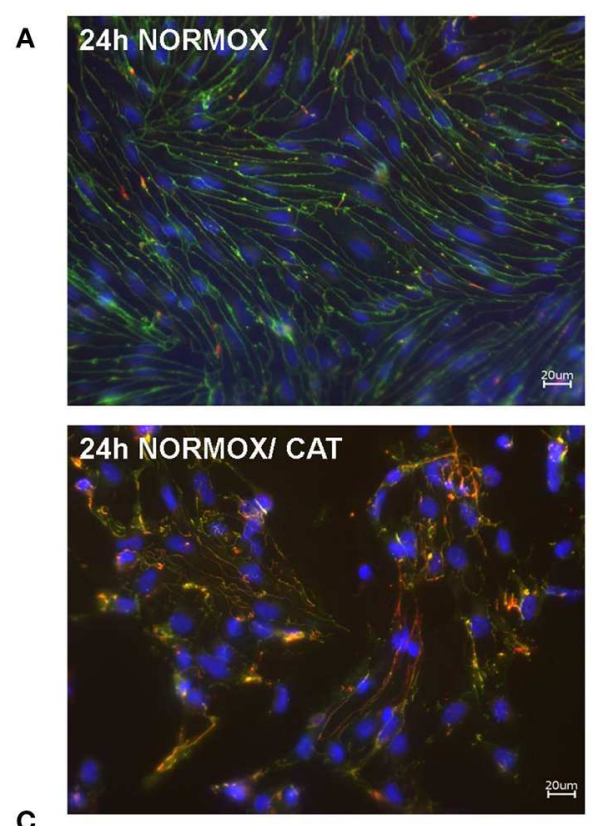

C

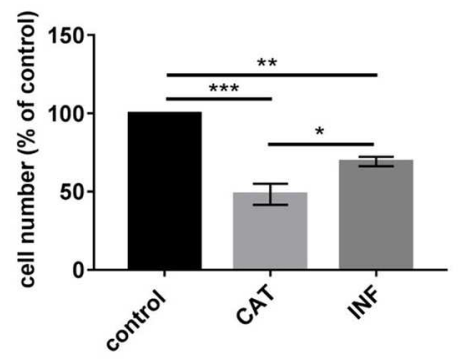

D

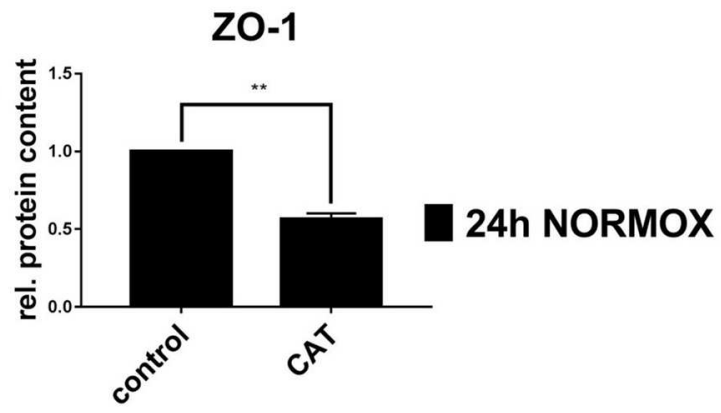

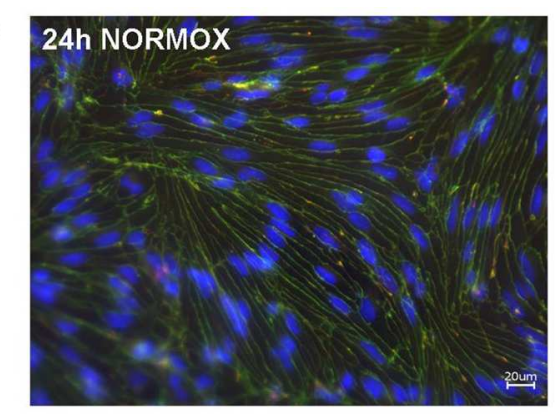

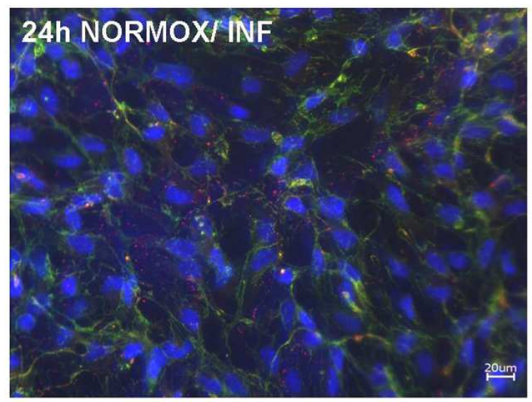

FIGURE 1 | Effects of catecholamines and inflammatory mediators under normoxia conditions on cEND cells. Cells were grown to confluence with subsequent differentiation. Catecholamines (CAT) or inflammatory mediators (INF) were applied for $24 \mathrm{~h}$ under normoxia conditions (24 h NORMOX). (A,B) Immunofluorescence staining of tight junction proteins claudin-5 (green) and ZO-1 (red) as markers of morphological changes of the endothelial cell monolayer. DAPI (blue) was used for staining of nuclei. Magnification 400 times, scale bar $20 \mu \mathrm{m}$. (C) Cell number after CAT and INF treatment normalized to control. (D) CAT induced changes of ZO-1 protein expression in CEND cells investigated by Western blot. Data is presented as the means ( \pm SEM) of $n=5$ independent experiments. Altered protein expression was normalized to $\beta$-actin. ZO-1 protein level changes are expressed as fold over untreated control, which was set $1 .{ }^{\star} P<0.05$, ${ }^{\star \star} P<0.01$, ${ }^{\star \star \star} P<0.001$.

monolayer changed slightly, while after $24 \mathrm{~h}$ of treatment, stress factors led to complete destruction of the cell monolayer (Figures 2A,B/stress factors) and a significant reduction of cell number (Figure 2E). Combination of OGD with stress factors potentiated these effects (Figures 2C/stress factors and Figure 2E). Morphologically, the most severe effect was caused by the administration of stress factors under reoxygenation conditions (Figure 2D/stress factors and Figure 2E). A typical morphological phenotype of cEND cells was no longer observed. The cells completely lost their spindle-shaped appearance and showed an irregular morphology without monolayer formation and significantly reduced cell numbers. Stained TJ proteins were visible as small aggregates outside the cell-cell contacts (Figure 2D/stress factors). 
TABLE 1 | Modulated target gene expression in cEND cells by elevated catecholamine levels or inflammatory mediators under normoxia conditions for $24 \mathrm{~h}$.

\begin{tabular}{|c|c|c|c|c|c|c|}
\hline & Claudin-5 & $Z O-1$ & Occludin & VE-cadherin & $\operatorname{ltg} \alpha 1$ & $\operatorname{ltg} \alpha \mathbf{v}$ \\
\hline CAT & $0.47 \pm 0.02^{\star \star \star}$ & $0.38 \pm 0.05^{\star \star \star}$ & $1.05 \pm 0.11$ n.s. & $0.55 \pm 0.02^{\star \star \star}$ & $0.19 \pm 0.02^{\star \star \star}$ & $1.82 \pm 0.24^{\star}$ \\
\hline INF & $1.18 \pm 0.21$ n.s. & $0.51 \pm 0.05^{\star \star \star}$ & $0.39 \pm 0.05^{\star * \star}$ & $0.85 \pm 0.02^{\star *}$ & $0.68 \pm 0.15$ n.s. & $3.31 \pm 0.54^{\star \star}$ \\
\hline
\end{tabular}

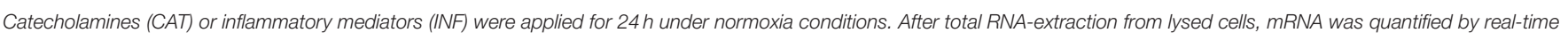

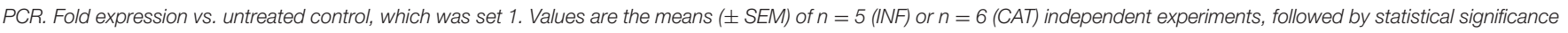
${ }^{\star} P<0.05,{ }^{\star \star} P<0.01,{ }^{\star \star *} P<0.001$. n.s, not significant.

\section{Elevated Catecholamine Levels and Inflammatory Mediators Combined With Oxygen Glucose Deprivation Cause a Change in Gene Expression}

We performed a real-time PCR, in order to investigate how the treatment with stress factors under different incubation conditions influences the gene expression of selected targets in cEND cells. First, we compared effects of stress factors under $4 \mathrm{~h}$ NORMOX, OGD, and REOX conditions, respectively (Table 2). Claudin-5 (0.49 \pm 0.07 -fold) and ZO-1 (0.7 \pm 0.08 fold) gene expression was downregulated by OGD alone but upregulated again after REOX (claudin-5 $0.88 \pm 0.07$-fold; $\mathrm{ZO}-11.26 \pm 0.06$-fold). This upregulation was not observed in combination with stress factor treatment. Similar changes were observed for occludin mRNA. VE-cadherin mRNA was significantly increased by OGD alone up to $1.56 \pm 0.11$-fold, followed by a decrease after REOX to $1.02 \pm 0.03$-fold. REOX in combination with stress factors caused a downregulation to $0.41 \pm 0.06$-fold of control. Integrin- $\alpha$ - 1 was induced by REOX alone up to $1.43 \pm 0.12$-fold, but reduced to 0.05 \pm 0.06 -fold after REOX in combination with stress factors. Integrin- $\alpha$-v mRNA was upregulated by OGD (4.08 \pm 0.72 fold), while REOX caused downregulation (1.0 \pm 0.04 -fold). Within the same incubation conditions, stress factors did not have significant effects on every target (Table 2). Under $4 \mathrm{~h}$ NORMOX conditions, gene expression of ZO-1, occludin and integrin- $\alpha-1$ was reduced by stress factors, whereas integrin$\alpha-\mathrm{v}$ was upregulated in comparison with untreated controls. OGD combined with stress factors affected mRNA levels of ZO1, occluding, and VE-cadherin compared to OGD alone. After reoxygenation combined with stress factors gene expression of claudin-5, ZO-1, VE-cadherin, and integrin- $\alpha-1$ was decreased in comparison with REOX alone. Subsequently, the data shown in Table 2 under REOX and REOX/stress factors were then used again in Table 3, but in this case the mRNA expression of selected targets was normalized to $24 \mathrm{~h}$ NORMOX (Table 3 ). The comparison in Table 2 enables an assessment of the gene expression over time, while Table 3 shows the mRNA levels only at $24 \mathrm{~h}$ point under various conditions. Claudin -5 gene expression did not change significantly after REOX with and without stress factor treatment. ZO-1 and VE-Cadherin consistently showed the same tendencies as claudin-5. The mRNA levels of occludin (1.35 \pm 0.07 -fold) and integrin- $\alpha$ 1 (1.32 \pm 0.07-fold), however, were upregulated by REOX, but only without stress factors. As already mentioned above, in this experiment stress factor administration did not have significant effects on every target as well (Table 3). Integrin- $\alpha-\mathrm{v}$ gene expression was induced by $24 \mathrm{~h}$ NORMOX in combination with stress factors ( $1.82 \pm 0.3$-fold) compared to $24 \mathrm{~h}$ NORMOX alone. No significant change of integrin- $\alpha$-v mRNA level by stress factor administration under REOX conditions was observed in comparison with REOX alone. However, REOX conditions combined with stress factor administration led to a significant decrease of the expression of all other target genes compared to REOX alone. Within $24 \mathrm{~h}$ NORMOX conditions stress factors caused reduced gene expression of claudin-5, ZO-1, occludin, VE-cadherin, and integrin- $\alpha-1$ as well. Interestingly, effects of stress factor administration under REOX conditions did not differ from those under $24 \mathrm{~h}$ NORMOX conditions. As already observed in immunofluorescence staining, the effects of stress factors under normoxia conditions evolved over time, especially in the case of claudin-5 (Tables 2,3). After $4 \mathrm{~h}$, mRNA levels of claudin-5 and VE-cadherin were not changed, whereas after $24 \mathrm{~h}$ of stress factor administration gene expression of all targets was significantly decreased.

\section{Protein Expression in cEND Cells Is Changed by Elevated Catecholamine Levels and Inflammatory Mediators Under Oxygen Glucose Deprivation Conditions}

As described above, differentiated cells were treated with stress factors under selected incubation conditions. To study changes in protein levels, cEND cells were lysed, and analyzed by Western Blot. Initially, protein levels were determined after administration of stress factors under OGD as well as REOX conditions in comparison with $4 \mathrm{~h}$ NORMOX conditions (Figure 3A). VE-cadherin expression was compromised by OGD to $0.57 \pm 0.07$-fold of control, followed by an increase up to $0.98 \pm 0.07$-fold after reoxygenation. This was not observed in combination with stress factors. Compared to the untreated control under the same incubation conditions, stress factors significantly influenced the protein content only in REOX samples. Claudin-5, occluding, and ZO-1 protein levels (all not shown) showed the same tendencies as VE-cadherin, but without statistical significance. Finally, changed protein levels after REOX were compared to $24 \mathrm{~h}$ NORMOX conditions (Figure 3B). Treatment with stress factors in combination with REOX led to an increase in occludin up to $0.81 \pm$ 0.03 -fold of control compared to stress factor administration under $24 \mathrm{~h}$ NORMOX conditions ( $0.49 \pm 0.07$-fold). Expression 


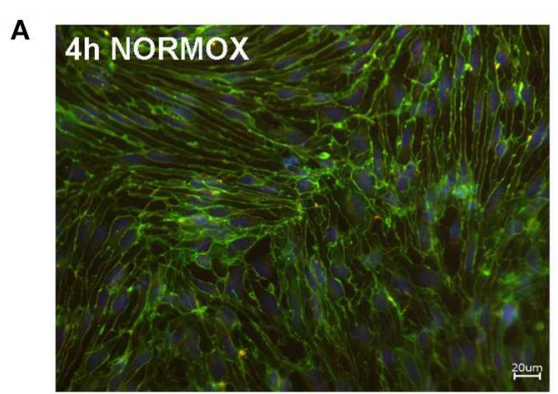

\section{B}
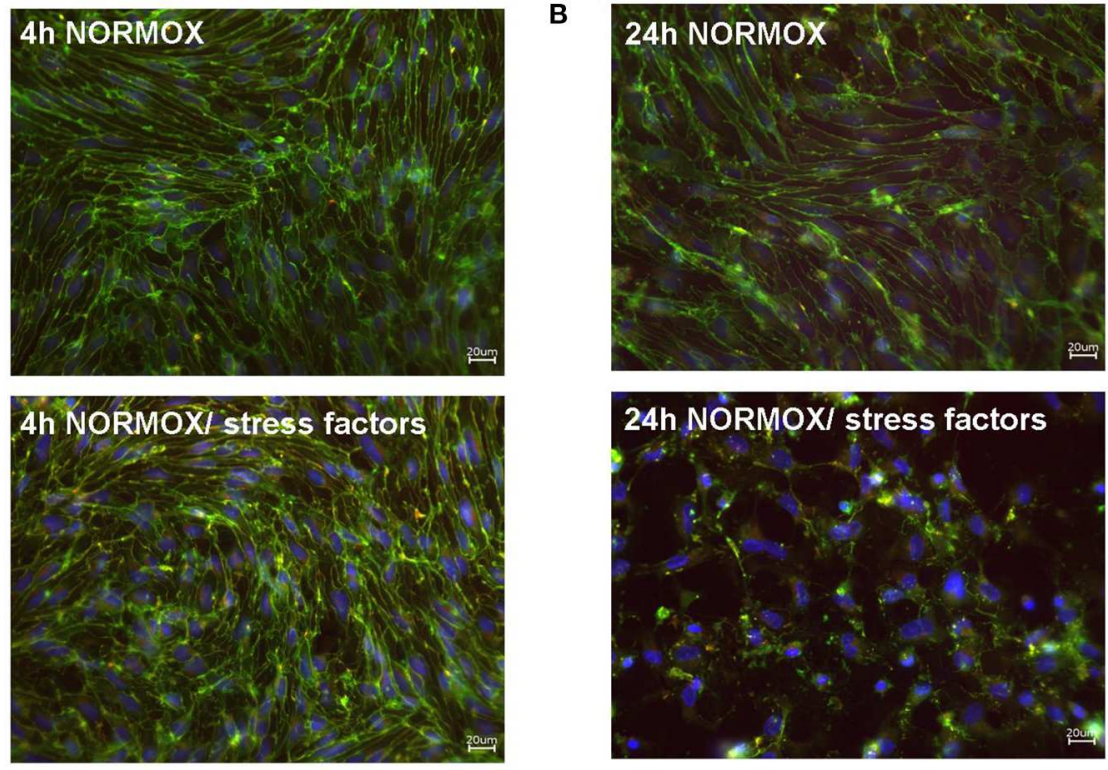

C

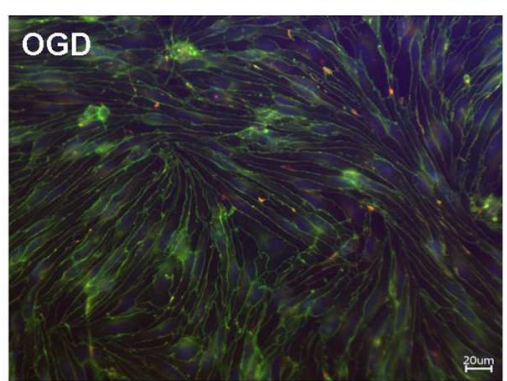

D
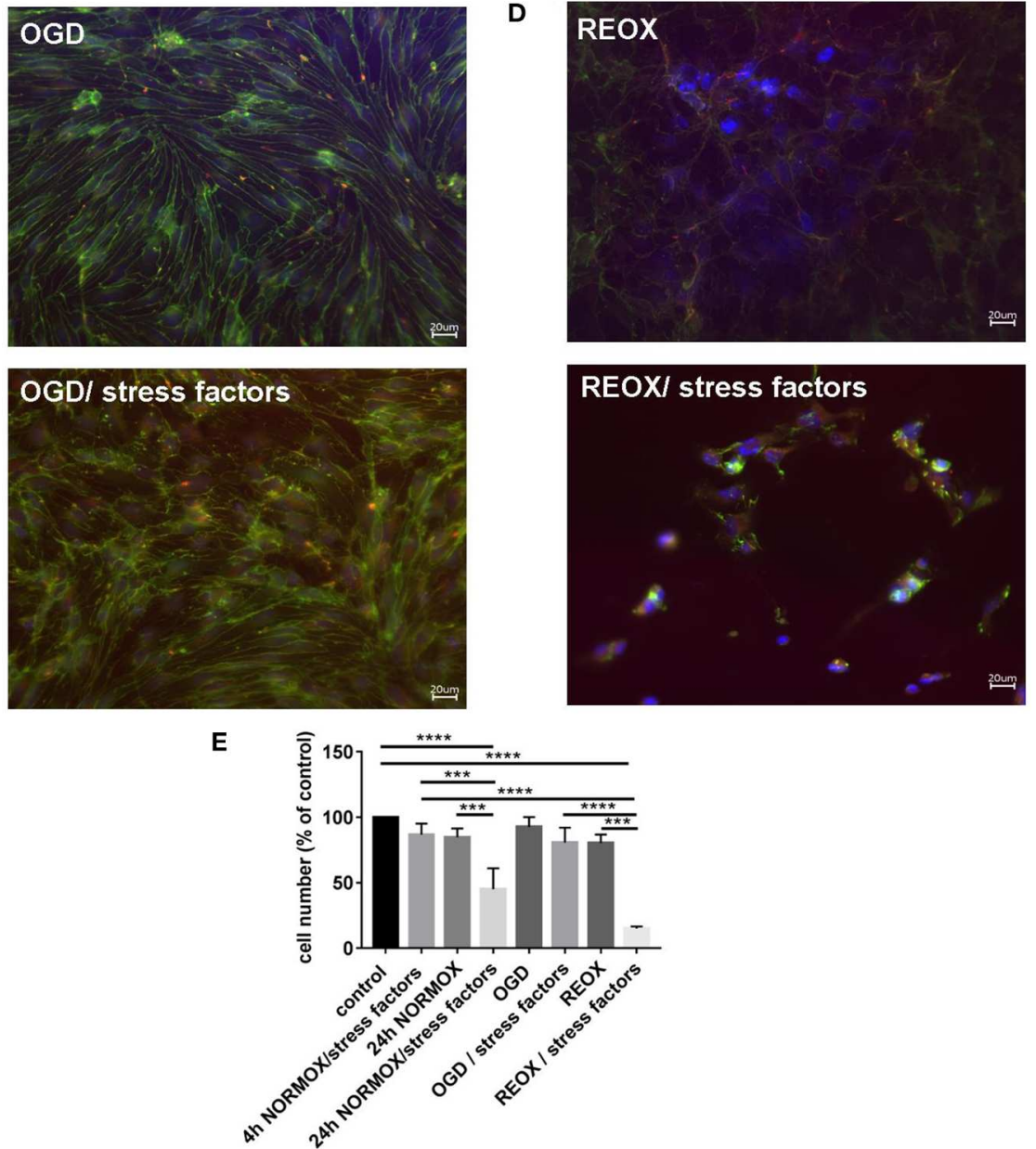

FIGURE 2 | Loss of morphological integrity of cEND cells exposed to elevated catecholamine levels and inflammatory mediators. Immunofluorescence staining of tight junction proteins claudin-5 (green) and ZO-1 (red) as markers of morphological changes of the endothelial cell monolayer. DAPI (blue) was used for staining 
FIGURE 2 | nuclei. Cells were grown on cover slips to confluence. After differentiation cEND cells were treated with combination of catecholamines and inflammatory mediators (stress factors). Stress factors were administered under different incubation conditions. Magnification 400 times, scale bar $20 \mu \mathrm{m}$. (A) Stress factor application for $4 \mathrm{~h}$ under normoxia conditions (4 h NORMOX). (B) Stress factor application for $24 \mathrm{~h}$ under normoxia conditions (24h NORMOX). (C). Stress factor application for $4 \mathrm{~h}$ under oxygen glucose deprivation conditions (OGD). (D) Stress factor application for $4 \mathrm{~h}$ under OGD conditions with $20 \mathrm{~h}$ of subsequent reoxygenation under normoxia conditions (REOX). (E) Cell number in treatments shown in (A-D) normalized to control. ${ }^{\star \star \star} P<0.001$, ${ }^{\star \star \star \star} P<0.0001$.

TABLE 2 | Modulated target gene expression in cEND cells by stress factors under oxygen glucose deprivation (OGD) conditions and after subsequent reoxygenation (REOX) in comparison with $4 \mathrm{~h}$ of normoxia (4 $\mathrm{h}$ NORMOX).

\begin{tabular}{|c|c|c|c|c|c|c|}
\hline & Claudin-5 & $\mathrm{ZO}-1$ & Occludin & VE-cadherin & $\operatorname{ltg} \alpha 1$ & $\operatorname{ltg} \alpha \mathbf{v}$ \\
\hline 4 h NORMOX & 1 & 1 & 1 & 1 & 1 & 1 \\
\hline $4 \mathrm{~h}$ NORMOX/stress factors & $\begin{array}{c}0.92 \pm 0.05 \\
\text { n.s. }\end{array}$ & $\underset{* \star}{0.3 \pm} 0.02$ & $\underset{* \star}{0.21 \pm} 0.02$ & $\begin{array}{c}0.73 \pm 0.07 \\
\text { n.s. }\end{array}$ & 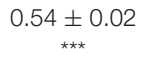 & $\begin{array}{c}3.8 \pm 0.6 \\
\star\end{array}$ \\
\hline OGD & $\begin{array}{c}0.49 \pm 0.07 \\
{ }^{\star \star \star} \S\end{array}$ & $\begin{array}{c}0.7 \pm 0.08 \\
{ }^{\star} \S\end{array}$ & $\begin{array}{c}0.34 \pm 0.06 \\
\star \star \star \S\end{array}$ & $\begin{array}{c}1.56 \pm 0.11 \\
{ }^{\star \star \star} \S\end{array}$ & $\begin{array}{c}0.69 \pm 0.05 \\
\text { n.s. } \S\end{array}$ & $\begin{array}{c}4.08 \pm 0.72 \\
{ }^{\star} \S\end{array}$ \\
\hline OGD/stress factors & $\begin{array}{c}0.56 \pm 0.11 \\
{ }^{\star \star} \&\end{array}$ & $\begin{array}{c}0.33 \pm 0.03 \\
* \star \star \$\end{array}$ & $\begin{array}{c}0.08 \pm 0.02 \\
* \star \star \$\end{array}$ & $\begin{array}{c}1.06 \pm 0.07 \\
\text { n.s.\$\& }\end{array}$ & $\underset{\substack{* \star \star \\
0.47}}{0.07}$ & $\underset{* \star \star}{6.5} \pm 1.08$ \\
\hline REOX & $\begin{array}{c}0.88 \pm 0.07 \\
\text { n.s. }\end{array}$ & $\begin{array}{c}1.26 \pm 0.06 \\
\text { n.s. }\end{array}$ & $\begin{array}{c}1.12 \pm 0.07 \\
\text { n.s. }\end{array}$ & $\begin{array}{c}1.03 \pm 0.03 \\
\text { n.s. }\end{array}$ & $\underset{* \star}{1.43} \pm 0.12$ & $\begin{array}{c} \pm 0.04 \\
\text { n.s. }\end{array}$ \\
\hline REOX/ stress factors & $\begin{array}{c}0.29 \pm 0.06 \\
{ }^{* \star \star} \# \%\end{array}$ & $\begin{array}{c}0.28 \pm 0.1 \\
\star \star \star \#\end{array}$ & $\begin{array}{c}0.26 \pm 0.05 \\
* \star \star \#\end{array}$ & $\begin{array}{c}0.41 \pm 0.06 \\
{ }^{\star \star \star} \# \% \mu\end{array}$ & $\begin{array}{c}0.05 \pm 0.06 \\
{ }^{* \star \star} \# \% \mu\end{array}$ & $\begin{array}{c}1.47 \pm 0.05 \\
\text { n.s. } \mu\end{array}$ \\
\hline
\end{tabular}

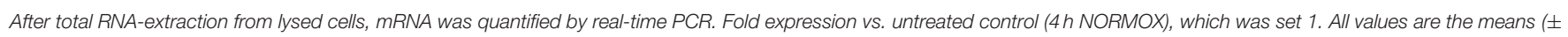

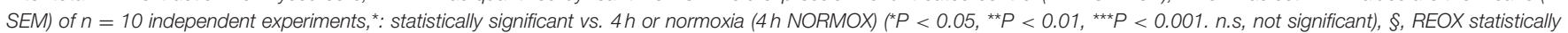

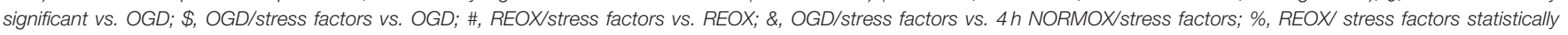
significant vs. $4 \mathrm{~h}$ NORMOX/ stress factors; $\mu$, REOX/stress factors statistically significant $v s$. OGD/stress factors.

of ZO-1 protein stayed unaffected by REOX conditions in comparison with $24 \mathrm{~h}$ NORMOX. Stress factors impaired significantly ZO-1 protein expression in both 24 NORMOX and REOX samples compared to untreated controls. Claudin5 and VE-cadherin (both not shown) showed the same tendencies. Similar to gene expression, the effects of stress factors under NORMOX conditions were apparently timedependent. All protein levels were significantly decreased after $24 \mathrm{~h}$ of stress factor administration, but not after $4 \mathrm{~h}$ exposure (Figures 3A,B).

\section{DISCUSSION}

The cardiovascular system is regulated by a central autonomic network consisting among others of the insular cortex, which is exposed to higher risk of cerebrovascular disease (10, 33). Damage in insular cortex has been associated with myocardial injury and TTS $(10,34)$. Based on clinical data, the simultaneous incidence of ischemic stroke and TTS has a poor outcome $(1,5,11)$. Increased CAT and INF levels are one of the TTS characteristics (6). To date, the molecular mechanisms underlying these events are not fully elucidated. We hypothesized that the characteristic clinical constellation of elevated CAT and INF levels combined with OGD leads to an aggravated breakdown of the BBB, which subsequently contributes to severe ischemic stroke and poor clinical outcomes. In this study, we used an in vitro $\mathrm{BBB}$ model to study the effects of CAT/INF/OGD treatment. To our best knowledge, this is the first report examining $\mathrm{BBB}$ properties under such conditions.
Breakdown of the BBB is a key feature of neuroinflammatory conditions as encountered in multiple sclerosis (MS), meningitis, brain tumors, encephalitis, and cerebral ischemia, which inevitably leads to weakening of the vessels and predisposing them to leakage and rupture (35-37). BBB breakdown in frame of TTS could potentially be mediated by the effects of pro-inflammatory cytokines and CAT forming the basis for increased vulnerability to cerebrovascular dysfunction and stroke. In serum of acute phase TTS patients elevated levels of CAT such as dopamine, epinephrine, and norepinephrine and the pro-inflammatory cytokines TNF $\alpha$, IL6, and IL10 have been reported $(6,38)$. In the pathology of ischemic stroke, TNF $\alpha$ and IL6 appear to be associated with BBB damage as seen on enhanced magnetic resonance imaging (MRI) scans (39). Using a rat model of experimental ischemia, it has been postulated that CAT are released in response to stress and ameliorate the ischemic brain damage (40). To address these observations at the molecular level, we decided to develop an in vitro pathology model of TTS based on our well-characterized murine brain endothelial cell line cEND (21). We previously validated this $\mathrm{BBB}$ model as suitable to study the barriercompromising effects of pro-inflammatory stimuli and OGD, demonstrating that incubation of cEND monolayers with $\mathrm{TNF} \alpha$ or OGD led to a down-regulation of TJ proteins and changes in pro-inflammatory cytokine expression (18, 20, 27, 41-43). Moreover, cEND express high levels of TJ, AJ, and ECM proteins and were used for permeability studies $(41,44,45)$. In this study, we expand our characterization to the combined barriercompromising effects of INF, CAT, and OGD conditions as partially encountered in acute phase TTS. We demonstrate 
TABLE 3 | Modulated target gene expression in cEND cells by stress factors under oxygen glucose deprivation with subsequent reoxygenation (REOX) in comparison with $24 \mathrm{~h}$ of normoxia ( $24 \mathrm{~h}$ NORMOX).

\begin{tabular}{|c|c|c|c|c|c|c|}
\hline & Claudin-5 & $Z O-1$ & Occludin & VE-cadherin & $\operatorname{ltg} \alpha 1$ & $\operatorname{ltg} \alpha \mathbf{v}$ \\
\hline 24 h NORMOX & 1 & 1 & 1 & 1 & 1 & 1 \\
\hline $\begin{array}{l}24 \text { h NORMOX/stress } \\
\text { factors }\end{array}$ & $\underset{* \star 2}{0.25} \pm 0.05$ & $\underset{* \star}{0.15 \pm 0.05}$ & 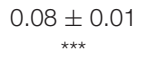 & $\begin{array}{c}0.46 \pm 0.05 \\
\star \star \star\end{array}$ & $\underset{\substack{* \star \star \\
0.19 \pm 0.05}}{0.05}$ & $\underset{* *}{1.82 \pm 0.3}$ \\
\hline REOX & $\begin{array}{c}0.87 \pm 0.03 \\
\text { n.s. }\end{array}$ & $\begin{array}{c}1.12 \pm 0.04 \\
\text { n.s. }\end{array}$ & $\underset{* \star * \star}{1.35 \pm 0.07}$ & $\begin{array}{c}1.05 \pm 0.03 \\
\text { n.s. }\end{array}$ & $\underset{* \star}{* \star} 0.07$ & $\begin{array}{c} \pm 0.04 \\
\text { n.s. }\end{array}$ \\
\hline REOX/stress factors & $\begin{array}{c}0.33 \pm 0.06 \\
{ }^{\star \star \star} \S\end{array}$ & $\begin{array}{c}0.24 \pm 0.08 \\
{ }^{\star \star \star} \S\end{array}$ & $\begin{array}{c}0.32 \pm 0.06 \\
* \star \star \S\end{array}$ & $\begin{array}{c}0.32 \pm 0.01 \\
\star \star \star \S\end{array}$ & $\begin{array}{c}0.05 \pm 0.01 \\
{ }^{\star \star \star} \S\end{array}$ & $\begin{array}{c}1.51 \pm 0.12 \\
\text { n.s. }\end{array}$ \\
\hline
\end{tabular}

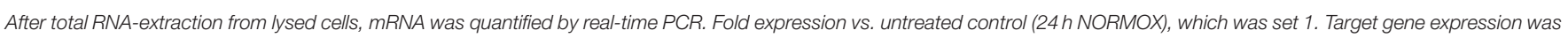

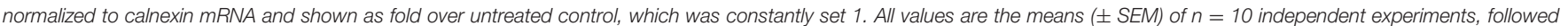

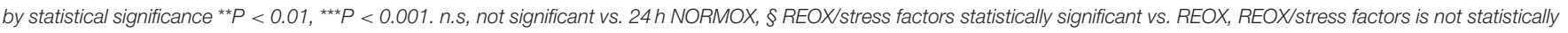
significant vs. $24 \mathrm{~h}$ NORMOX/stress factors.

compromised endothelial barrier function and reduced or altered junctional protein expression, resulting from incubation of cEND with (i) INF of TTS, (ii) with CAT elevated in TTS or, (iii) the combination of INF and CAT. As markers of BBB disruption we chose a barrier-integrity representing targets such the $\mathrm{TJ}$ and AJ components Cldn5, occludin, ZO-1, and VE-cadherin. As markers for interaction with ECM we chose Itg $\alpha 1$ and Itg $\alpha \mathrm{v}$, which were previously demonstrated to be altered in inflammatory processes (32). We observed an alteration in cellular morphology and cell number following incubation of cEND monolayers with TTS acute phase CAT/INF administered separately and simultaneously. Under normoxic conditions, morphology, monolayer integrity, cell number as well as TJ forming protein levels were more affected by incubation with CAT than INF. This was significantly mirrored at the expression level of analyzed marker proteins. Messenger RNA levels of ZO-1 and VE-cadherin were reduced by both treatments, while occludin was downregulated by INF, and claudin- 5 by CAT. Expression levels of Itg $\alpha 1$ was reduced in response to INF/CAT treatment. Concomitantly, an upregulation of the $\alpha \mathrm{V}$ of vitronectin was observed. Matching data supporting the important role of functional integrin-ECM binding have been demonstrated in vivo, while breakdown of the $\mathrm{BBB}$ has been observed in mice lacking selected integrins (46). In addition, altered expression patterns of specifically Itg $\alpha 1$ and Itg $\alpha \mathrm{V}$ have been observed in MS lesions (47). The influence of altered integrin expression pattern on cellular differentiation has been described in integrin knock out mice and for epithelial and endothelial cells in vitro $(32,48,49)$. Moreover, a role of integrins in epithelial barrier formation has been described in mammary epithelial cells (50). This supports the notion that a reduction of Itg $\alpha 1$ levels with concomitant increase in Itg $\alpha \mathrm{v}$ levels can be considered a reliable marker of endothelial inflammation in TTS as well.

Increasing the permeability of the endothelial barrier caused by impaired cell-cell adhesion is believed to be an early event in ischemic stroke (51). Accordingly, increased barrier breakdown was observed under OGD with common TTS stressors, most notably under OGD/REOX conditions corresponding to ischemia-reperfusion injury. Monolayer morphology, monolayer integrity, and cell count were significantly affected in response to INF/CAT in OGD. CAT is known to induce apoptosis. CAT treatment of oligodendrocytes cultures induced apoptosis mediated by oxidative stress (52). TNF $\alpha$ induces apoptosis in human endothelial cells of various vascular beds $(53,54)$. A combination of all these factors escalated the effects on cEND and resulted in significant cell loss. Morphological changes were accompanied by decreased protein and mRNA levels of marker proteins. Interestingly, occludin, ZO-1, and Itg $\alpha 1$ were more affected by INF/CAT than claudin-5. These results indicate a susceptibility of ZO-1 and Itg $\alpha 1$ to INF/CAT/OGD, which are both key components of TJ complexes and cell matrix, respectively. The effect of the administered stress factors is time-dependent and does not have the same dimension for each target chosen. In addition, stress factors only partially amplify OGD effects. Possible intracellular pathways that may mediate the effects of supra-physiological CAT concentrations on cEND monolayers will have to be investigated in future studies. However, available literature information points toward a role for $\beta$-adrenergic stimulation (and cAMP mobilization) as an important barrier enhancing mechanism: (i) Chi et al. showed that a direct application of a beta-adrenergic receptor agonist to the brain parenchyma increased the permeability of the $\mathrm{BBB}$, and that this effect could be prevented with a beta-adrenoceptor antagonist (55). (ii) Murphy and Johanson had proven the adrenergic-induced enhancement of brain barrier system permeability to small nonelectrolytes (56). (iii) A possible molecular pathway that could be involved is highlighted by the work of Ohara et al. (57). The beta 2-adrenergic receptor/cAMP pathway was shown to be involved in $\mathrm{TNF} \alpha$ stimulated ICAM-1 expression, which indicates the possible involvement of adrenergic mediation of $\mathrm{BBB}$ integrity, given (iiii) that the physiological role of ICAM-1 is to mediate neutrophil BBB transmigration (58). (iiiii) Neutrophils in turn mediate immune cell mediated communication between the immune system and the brain, which is specifically enhanced in systemic inflammatory insults that can exacerbate ongoing brain pathologies via immune cell trafficking (59).

An important limitation of the present study is that we only analyzed selected stress factors present in TTS in vitro. 
A

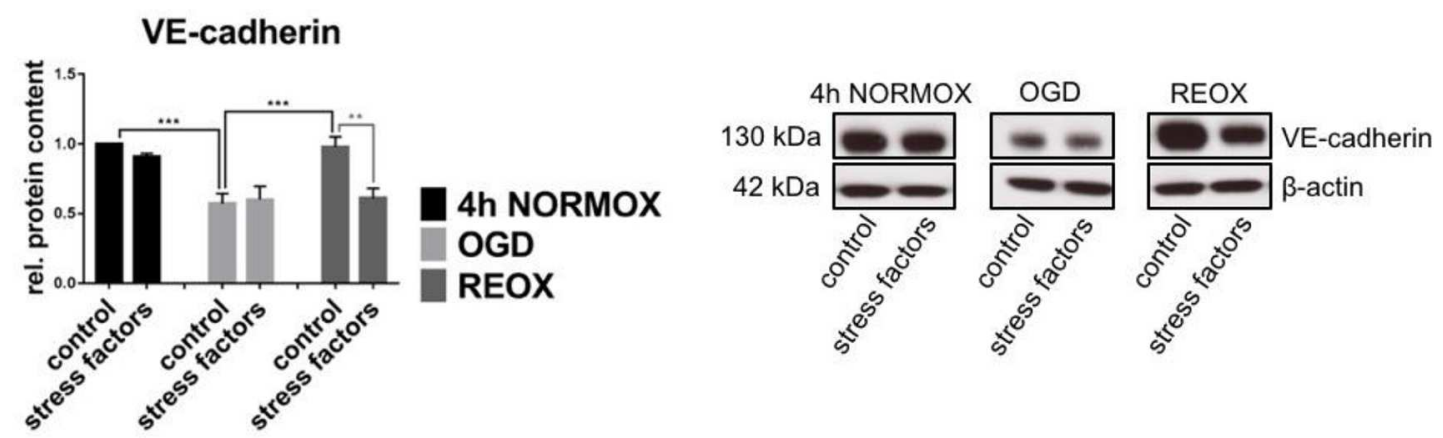

B
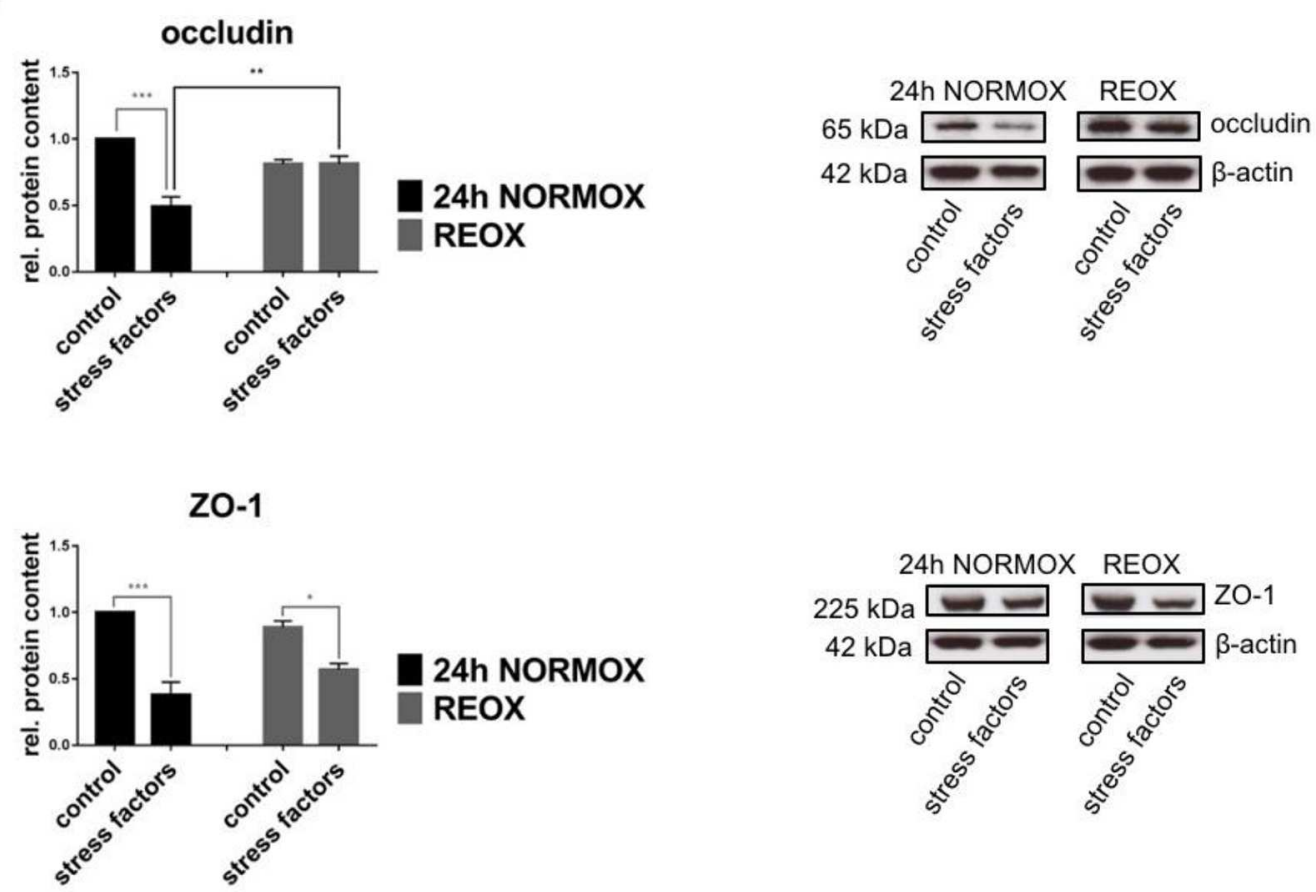

FIGURE 3 | Protein expression in cEND cells is changed by elevated catecholamine levels and inflammatory mediators under oxygen glucose deprivation conditions. Cells were grown to confluence with subsequent differentiation. Stress factors were applied under different incubation conditions. Protein levels were examined by Western blot. Changed protein expression was normalized to $\beta$-actin. Changes of protein levels determined by densitometric analysis are expressed as fold over untreated control, which was set as 1. (A) VE-cadherin protein expression after stress factor administration under oxygen glucose deprivation conditions (OGD) and subsequent reoxygenation (REOX) in comparison with $4 \mathrm{~h}$ of normoxia ( $4 \mathrm{~h}$ NORMOX). Values are the means $( \pm \mathrm{SEM}$ ) of $n=8$ independent experiments. (B) Occludin and ZO-1 protein levels changed by stress factors after reoxygenation conditions (REOX) compared to $24 \mathrm{~h}$ of normoxia conditions (24 $\mathrm{h}$ NORMOX). Values are the means ( \pm SEM) of $n=10$ independent experiments. ${ }^{*} P<0.05,{ }^{* \star} P<0.01,{ }^{* \star *} P<0.001$.

It is not clear, how the observed effects develop in vivo over time. In vitro, a stable concentration of stressors without preconditioning was used. In this model, we cannot determine whether increasing stress factors will affect the BBB in other ways over time. In addition, we used a simplified BBB in vitro model based on only one cell type, the brain microvascular endothelial cells, derived from mice. Other neurovascular unit cells such as pericytes and astrocytes are known to play an important role in maintaining the barrier in vivo and in vitro $(60,61)$. Differences in species could also play a role in our system (62). Therefore, studies with TTS stress factors will be carried out in future using a human in vitro $\mathrm{BBB}$ model in co-culture with astrocytes and pericytes.

\section{CONCLUSION}

In summary, the present study provides the first evidence for the impairment of BBB by TTS stressors, CAT, and INF. In 
addition, the barrier-compromising effects of CAT and INF were highest during the reoxygenation phase, suggesting that TTS stressors along with other pathophysiological mechanisms, could contribute to secondary brain damage after stroke.

\section{DATA AVAILABILITY STATEMENT}

All datasets generated for this study are included in the article/ supplementary material.

\section{REFERENCES}

1. Jung JM, Kim JG, Kim JB, Cho KH, Yu S, Oh K, et al. Takotsubolike myocardial dysfunction in ischemic stroke: a hospital-based registry and systematic literature review. Stroke. (2016) 47:2729-36. doi: 10.1161/STROKEAHA.116.014304

2. Said SM, Saygili E, Rana OR, Genz C, Hahn J, Bali R, et al. Takotsubo cardiomyopathy: what we have learned in the last 25 years? a comparative literature review. Curr Cardiol Rev. (2016) 12:297-303. doi: 10.2174/1573403X12666160211125601

3. Prasad A, Lerman A, Rihal CS. Apical ballooning syndrome (tako-tsubo or stress cardiomyopathy): a mimic of acute myocardial infarction. Am Heart J. (2008) 155:408-17. doi: 10.1016/j.ahj.2007.11.008

4. Eitel I, Von Knobelsdorff-Brenkenhoff F, Bernhardt P, Carbone I, Muellerleile $\mathrm{K}$, Aldrovandi A, et al. Clinical characteristics and cardiovascular magnetic resonance findings in stress (takotsubo) cardiomyopathy. JAMA. (2011) 306:277-86. doi: 10.1001/jama.2011.992

5. Dande AS, Pandit AS, Galin ID. Takotsubo cardiomyopathy followed by neurogenic stunned myocardium in the same patient: gradations of the same disease? Cardiology. (2011) 118:175-8. doi: 10.1159/000328464

6. Pelliccia F, Kaski JC, Crea F, Camici PG. Pathophysiology of takotsubo syndrome. Circulation. (2017) 135:2426-41. doi: 10.1161/CIRCULATIONAHA.116.027121

7. Jin R, Liu L, Zhang S, Nanda A, Li G. Role of inflammation and its mediators in acute ischemic stroke. J Cardiovasc Transl Res. (2013) 6:834-51. doi: $10.1007 /$ s12265-013-9508-6

8. Piccardi B, Giralt D, Bustamante A, Llombart V, Garcia-Berrocoso T, Inzitari D, et al. Blood markers of inflammation and endothelial dysfunction in cardioembolic stroke: systematic review and meta-analysis. Biomarkers. (2017) 22:200-9. doi: 10.1080/1354750X.2017.1286689

9. Chen Z, Venkat P, Seyfried D, Chopp M, Yan T, Chen J. Brain-heart interaction: cardiac complications after stroke. Circ Res. (2017) 121:451-68. doi: 10.1161/CIRCRESAHA.117.311170

10. Nagai M, Dote K, Kato M, Sasaki S, Oda N, Kagawa E, et al. The insular cortex and takotsubo cardiomyopathy. Curr Pharm Des. (2017) 23:879-88. doi: $10.2174 / 1381612822666161006123530$

11. Nagai M, Hoshide S, Kario K. The insular cortex and cardiovascular system: a new insight into the brain-heart axis. J Am Soc Hypertens. (2010) 4:174-82. doi: 10.1016/j.jash.2010.05.001

12. Yoshimura S, Toyoda K, Ohara T, Nagasawa H, Ohtani N, Kuwashiro T, et al. Takotsubo cardiomyopathy in acute ischemic stroke. Ann Neurol. (2008) 64:547-54. doi: 10.1002/ana.21459

13. Daneman R, Prat A. The blood-brain barrier. Cold Spring Harb Perspect Biol. (2015) 7:a020412. doi: 10.1101/cshperspect.a020412

14. Chow BW, Gu C. The molecular constituents of the blood-brain barrier. Trends Neurosci. (2015) 38:598-608. doi: 10.1016/j.tins.2015.08.003

15. Serlin Y, Shelef I, Knyazer B, Friedman A. Anatomy and physiology of the blood-brain barrier. Semin Cell Dev Biol. (2015) 38:2-6. doi: $10.1016 /$ j.semcdb.2015.01.002

16. Forster C. Tight junctions and the modulation of barrier function in disease. Histochem Cell Biol. (2008) 130:55-70. doi: 10.1007/s00418-008-0424-9

17. Blecharz-Lang KG, Wagner J, Fries A, Nieminen-Kelha M, Rosner J, Schneider UC, et al. Interleukin 6-mediated endothelial barrier disturbances

\section{AUTHOR CONTRIBUTIONS}

CI performed experiments and wrote the manuscript. CI, MB, SS, $\mathrm{MN}$, and CF designed the experiments, analyzed, and interpreted the data. All authors critically revised the manuscript.

\section{ACKNOWLEDGMENTS}

We thank Elisabeth Wilken and Anja Neuhoff for their excellent technical assistance.

can be attenuated by blockade of the IL6 receptor expressed in brain microvascular endothelial cells. Transl Stroke Res. (2018) 9:631-42. doi: 10.1007/s12975-018-0614-2

18. Silwedel C, Forster C. Differential susceptibility of cerebral and cerebellar murine brain microvascular endothelial cells to loss of barrier properties in response to inflammatory stimuli. J Neuroimmunol. (2006) 179:37-45. doi: 10.1016/j.jneuroim.2006.06.019

19. Semenas E, Sharma HS, Wiklund L. Adrenaline increases blood-brainbarrier permeability after haemorrhagic cardiac arrest in immature pigs. Acta Anaesthesiol Scand. (2014) 58:620-9. doi: 10.1111/aas.12293

20. Kleinschnitz C, Blecharz K, Kahles T, Schwarz T, Kraft P, Gobel K, et al. Glucocorticoid insensitivity at the hypoxic blood-brain barrier can be reversed by inhibition of the proteasome. Stroke. (2011) 42:1081-9. doi: 10.1161/STROKEAHA.110.592238

21. Forster C, Silwedel C, Golenhofen N, Burek M, Kietz S, Mankertz J, et al. Occludin as direct target for glucocorticoid-induced improvement of bloodbrain barrier properties in a murine in vitro system. J Physiol. (2005) 565:475-86. doi: 10.1113/jphysiol.2005.084038

22. Burek M, Salvador E, Forster CY. Generation of an immortalized murine brain microvascular endothelial cell line as an in vitro blood brain barrier model. $J$ Vis Exp. (2012) 29:e4022. doi: 10.3791/4022

23. Helms HC, Abbott NJ, Burek M, Cecchelli R, Couraud PO, Deli MA, et al. In vitro models of the blood-brain barrier: an overview of commonly used brain endothelial cell culture models and guidelines for their use. J Cereb Blood Flow Metab. (2016) 36:862-90. doi: 10.1177/0271678X16630991

24. Dukes AA, Van Laar VS, Cascio M, Hastings TG. Changes in endoplasmic reticulum stress proteins and aldolase $\mathrm{A}$ in cells exposed to dopamine. J Neurochem. (2008) 106:333-46. doi: 10.1111/j.1471-4159.2008.0 5392.x

25. Ali A, Diebel L, Liberati D. Stress hormone epinephrine increases IgA transport across respiratory epithelial surfaces. J Am Coll Surg. (2014) 218:450-8. doi: 10.1016/j.jamcollsurg.2013.11.011

26. Shao YY, Lin H, Li YS, Lee YH, Chen HM, Cheng AL, et al. High plasma interleukin-6 levels associated with poor prognosis of patients with advanced hepatocellular carcinoma. Jpn J Clin Oncol. (2017) 47:949-53. doi: $10.1093 / \mathrm{jjco} / \mathrm{hyx} 103$

27. Salvador E, Burek M, Forster CY. Stretch and/or oxygen glucose deprivation (OGD) in an in vitro traumatic brain injury (TBI) model induces calcium alteration and inflammatory cascade. Front Cell Neurosci. (2015) 9:323. doi: 10.3389/fncel.2015.00323

28. Blecharz KG, Burek M, Bauersachs J, Thum T, Tsikas D, Widder J, et al. Inhibition of proteasome-mediated glucocorticoid receptor degradation restores nitric oxide bioavailability in myocardial endothelial cells in vitro. Biol Cell. (2014) 106:219-35. doi: 10.1111/boc.201300083

29. Gotsch U, Borges E, Bosse R, Boggemeyer E, Simon M, Mossmann H, et al. VE-cadherin antibody accelerates neutrophil recruitment in vivo. J Cell Sci. (1997) 110:583-8.

30. Dilling C, Roewer N, Forster CY, Burek M. Multiple protocadherins are expressed in brain microvascular endothelial cells and might play a role in tight junction protein regulation. J Cereb Blood Flow Metab. (2017) 37:3391-400. doi: 10.1177/0271678X16688706

31. Defilippi P, Van Hinsbergh V, Bertolotto A, Rossino P, Silengo L, Tarone G. Differential distribution and modulation of expression of alpha $1 /$ beta 
1 integrin on human endothelial cells. J Cell Biol. (1991) 114:855-63. doi: $10.1083 /$ jcb.114.4.855

32. Forster C, Kahles T, Kietz S, Drenckhahn D. Dexamethasone induces the expression of metalloproteinase inhibitor TIMP-1 in the murine cerebral vascular endothelial cell line cEND. J Physiol. (2007) 580:937-49. doi: 10.1113/jphysiol.2007.129007

33. Marins FR, Iddings JA, Fontes MA, Filosa JA. Evidence that remodeling of insular cortex neurovascular unit contributes to hypertension-related sympathoexcitation. Physiol Rep. (2017) 5:e13156. doi: 10.14814/phy2.13156

34. Nagai $M$, Dote $K$, Kato $M$. Central autonomic network and takotsubo cardiomyopathy: how left insular cortex interact? Eur Heart J. (2019) 40:3061. doi: 10.1093/eurheartj/ehz476

35. Hamann GF, Okada Y, Fitridge R, Del Zoppo GJ. Microvascular basal lamina antigens disappear during cerebral ischemia and reperfusion. Stroke. (1995) 26:2120-6. doi: 10.1161/01.STR.26.11.2120

36. Rosenberg GA. Matrix metalloproteinases and neuroinflammation in multiple sclerosis. Neuroscientist. (2002) 8:586-95. doi: 10.1177/1073858402238517

37. Sellner J, Leib SL. In bacterial meningitis cortical brain damage is associated with changes in parenchymal MMP-9/TIMP-1 ratio and increased collagen type IV degradation. Neurobiol Dis. (2006) 21:647-56. doi: 10.1016/j.nbd.2005.09.007

38. Wilson HM, Cheyne L, Brown PAJ, Kerr K, Hannah A, Srinivasan J, et al. (2018). Characterization of the myocardial inflammatory response in acute stress-induced (takotsubo) cardiomyopathy. JACC Basic Transl Sci. 3:766-78. doi: 10.1016/j.jacbts.2018.08.006

39. Hotter B, Hoffmann S, Ulm L, Meisel C, Fiebach JB, Meisel A. IL-6 plasma levels correlate with cerebral perfusion deficits and infarct sizes in stroke patients without associated infections. Front Neurol. (2019) 10:83. doi: 10.3389/fneur.2019.00083

40. Koide T, Wieloch TW, Siesjo BK. Circulating catecholamines modulate ischemic brain damage. J Cereb Blood Flow Metab. (1986) 6:559-65. doi: $10.1038 /$ jcbfm. 1986.102

41. Burek M, Konig A, Lang M, Fiedler J, Oerter S, Roewer N, et al. Hypoxiainduced MicroRNA-212/132 alter blood-brain barrier integrity through inhibition of tight junction-associated proteins in human and mouse brain microvascular endothelial cells. Transl Stroke Res. (2019) 10:672-83. doi: 10.1007/s12975-018-0683-2

42. Blecharz KG, Haghikia A, Stasiolek M, Kruse N, Drenckhahn D, Gold R, et al. Glucocorticoid effects on endothelial barrier function in the murine brain endothelial cell line cEND incubated with sera from patients with multiple sclerosis. Mult Scler. (2010) 16:293-302. doi: 10.1177/1352458509358189

43. Burek M, Haghikia A, Gold R, Roewer N, Chan A, Förster CY. Differential cytokine release from brain microvascular endothelial cells treated with dexamethasone and multiple sclerosis patient sera. J Steroids Hormonal Sci. (2014) 5:128. doi: 10.4172/2157-7536.1000128

44. Blecharz-Lang KG, Prinz V, Burek M, Frey D, Schenkel T, Krug SM, et al. Gelatinolytic activity of autocrine matrix metalloproteinase-9 leads to endothelial de-arrangement in moyamoya disease. J Cereb Blood Flow Metab. (2018) 38:1940-53. doi: 10.1177/0271678X18768443

45. Kaiser M, Burek M, Britz S, Lankamp F, Ketelhut S, Kemper B, et al. The influence of capsaicin on the integrity of microvascular endothelial cell monolayers. Int J Mol Sci. (2018) 20:122. doi: 10.3390/ijms20010122

46. Del Zoppo GJ, Milner R. Integrin-matrix interactions in the cerebral microvasculature. Arterioscler Thromb Vasc Biol. (2006) 26:1966-75. doi: 10.1161/01.ATV.0000232525.65682.a2

47. Sobel RA, Hinojoza JR, Maeda A, Chen M. Endothelial cell integrin laminin receptor expression in multiple sclerosis lesions. Am J Pathol. (1998) 153:405-15. doi: 10.1016/S0002-9440(10)65584-8

48. Sheppard D. In vivo functions of integrins: lessons from null mutations in mice. Matrix Biol. (2000) 19:203-9. doi: 10.1016/S0945-053X(00)00065-2
49. Gumbiner BM. Cell adhesion: the molecular basis of tissue architecture and morphogenesis. Cell. (1996) 84:345-57. doi: 10.1016/S0092-8674(00)8 $1279-9$

50. Forster C, Makela S, Warri A, Kietz S, Becker D, Hultenby K, et al. Involvement of estrogen receptor beta in terminal differentiation of mammary gland epithelium. Proc Natl Acad Sci USA. (2002) 99:15578-83. doi: 10.1073/pnas. 192561299

51. Griemert EV, Recarte Pelz K, Engelhard K, Schafer MK, Thal SC. PAI-1 but Not PAI-2 gene deficiency attenuates ischemic brain injury after experimental stroke. Transl Stroke Res. (2019) 10:372-80. doi: 10.1007/s12975-018-0644-9

52. Khorchid A, Fragoso G, Shore G, Almazan G. Catecholamine-induced oligodendrocyte cell death in culture is developmentally regulated and involves free radical generation and differential activation of caspase-3. Glia. (2002) 40:283-99. doi: 10.1002/glia.10123

53. Deshpande SS, Angkeow P, Huang J, Ozaki M, Irani K. Rac1 inhibits TNFalpha-induced endothelial cell apoptosis: dual regulation by reactive oxygen species. FASEB J. (2000) 14:1705-14. doi: 10.1096/fj.99-0910com

54. Lopez-Ramirez MA, Fischer R, Torres-Badillo CC, Davies HA, Logan $\mathrm{K}$, Pfizenmaier $\mathrm{K}$, et al. Role of caspases in cytokine-induced barrier breakdown in human brain endothelial cells. J Immunol. (2012) 189:3130-9. doi: 10.4049/jimmunol.1103460

55. Chi OZ, Wang G, Chang Q, Weiss HR. Effects of isoproterenol on blood-brain barrier permeability in rats. Neurol Res. (1998) 20:259-64. doi: 10.1080/01616412.1998.11740516

56. Murphy VA, Johanson CE. Adrenergic-induced enhancement of brain barrier system permeability to small nonelectrolytes: choroid plexus versus cerebral capillaries. J Cereb Blood Flow Metab. (1985) 5:401-12. doi: $10.1038 / \mathrm{jcbfm} .1985 .55$

57. Ohara Y, Mccarron RM, Hoffman TT, Sugano H, Bembry J, Lenz FA, et al. Adrenergic mediation of TNF alpha-stimulated ICAM-1 expression on human brain microvascular endothelial cells. Acta Neurochir Suppl. (2000) 76:117-20. doi: 10.1007/978-3-7091-6346-7_24

58. Lyck R, Enzmann G. The physiological roles of ICAM-1 and ICAM-2 in neutrophil migration into tissues. Curr Opin Hematol. (2015) 22:53-9. doi: 10.1097/MOH.0000000000000103

59. Pflieger FJ, Hernandez J, Schweighofer H, Herden C, Rosengarten B, Rummel C. The role of neutrophil granulocytes in immune-to-brain communication. Temperature. (2018) 5:296-307. doi: 10.1080/23328940.2018.1538598

60. Armulik A, Genove G, Mae M, Nisancioglu MH, Wallgard E, Niaudet C, et al. Pericytes regulate the blood-brain barrier. Nature. (2010) 468:557-61. doi: 10.1038/nature09522

61. Neuhaus W, Gaiser F, Mahringer A, Franz J, Riethmuller C, Forster C. The pivotal role of astrocytes in an in vitro stroke model of the blood-brain barrier. Front Cell Neurosci. (2014) 8:352. doi: 10.3389/fncel.2014.00352

62. Urich E, Lazic SE, Molnos J, Wells I, Freskgard PO. Transcriptional profiling of human brain endothelial cells reveals key properties crucial for predictive in vitro blood-brain barrier models. PLoS ONE. (2012) 7:e38149. doi: 10.1371/journal.pone.0038149

Conflict of Interest: The authors declare that the research was conducted in the absence of any commercial or financial relationships that could be construed as a potential conflict of interest.

Copyright $\odot 2020$ Ittner, Burek, Störk, Nagai and Förster. This is an open-access article distributed under the terms of the Creative Commons Attribution License (CC $B Y)$. The use, distribution or reproduction in other forums is permitted, provided the original author(s) and the copyright owner(s) are credited and that the original publication in this journal is cited, in accordance with accepted academic practice. No use, distribution or reproduction is permitted which does not comply with these terms. 